\title{
Maoism in South America: Comparing Peru's Sendero Luminoso with Mexico's PRP and PPUA
}

Kevin Pinkoski

\begin{abstract}
This paper attempts to test to what level the distinction can be made between Maoism, Mao Tse-Sung's theory of revolutionary communism, as it functioned in China during the People's Revolution and in South America. This paper will compare the Maoist ideology of two Maoist leaders and their revolutionary movements: Mexico’s Florencio Medrano and Peru's Abimael Guzman.
\end{abstract}

\section{Introduction}

Maoism, Mao Tse-Sung's theory of revolutionary communism, offered an interpretation of Marxism inspired by the political reality of China. Like other leftist movements, Maoism managed to create both global influence and revolutionary movements. This "success" was based in both Maoism's diagnosis of imperialism and in its interpretation of socialism. ${ }^{1}$ Mao criticized both the Cold War's "First World" and "Second World" for their attempts to dominate the politics of the "Third World's" development. ${ }^{2}$ True socialism can only be attainable in the "Third World," where marginalized classes have not been brought up through imperialism. ${ }^{3}$ This phenomenon is only possible through a People's War, which is to be understood as armed action taken by the masses in an attempt to remove both the bourgeois and their institutions. ${ }^{4}$ The final result was therefore an established society that uses anti-feudal economics based in agrarian socialism. ${ }^{5}$ This process, as outlined by Mao, departed from traditional Marxism, and Marxism's emphasis on urbanized industry. Instead, Maoism emphasized an end to urban/rural division and other economic discrepancies created by imperialism and the bourgeois. As a result, Maoism became a popular revolutionary example for movements outside the "First" and "Second" world dichotomy. Maoism was therefore especially significant in South American revolutionary movements, movements that desired a true autonomy from imperial influence.

Maoism offered a complete socialist theory for the creation of a new economic system. In comparison to other Marxist movements, Maoism relied on two distinctive differences. The first difference was in Mao's economic foundations, which expanded beyond industrialization. The second difference was in Mao's model for revolution. This model was based specifically in both a mass movement and an agrarian understanding of a proletariat. Both of these factors were significant in understanding global Maoist trends. However, when comparing South American Maoist movements, Matthew Rothwell argued that "a basic division can be drawn between those who were most interested in China as a model for economic development in a Third World country,

\footnotetext{
${ }^{1}$ V.A. Krivtsov. "Introduction" in Maoism Unmasked (Moscow: Progress Publishers, 1972). 7

2 Ibid., 8

${ }^{3}$ Ibid., 22

${ }^{4}$ Ibid., 18

${ }^{5}$ Ibid., 23
} 
and those who saw China as offering a model experience for revolutionary warfare." ${ }^{6}$ Rothwell admitted there were no specific distinction between movements that embraced either Maoism's militarism or economic development, while this paper attempts to test to what level this distinction can be made. This paper will compare the Maoist ideology of two Maoist leaders and their revolutionary movements: Mexico's Florencio Medrano and Peru's Abimael Guzman. This will serve to evaluate the application of Mao's theory in the Third World.

Medrano was the leader of the PRP (Partido Revolucianario del Proletariado) in 1973 and the PPUA (Partido Proletario Unido de America) from 1973 to 1978. Both the PRP and PPUA were radical movements that attempted to organize Mexico's south-central peasants against land ownership in an attempt to initiate actions against global economic systems. Medrano was born into a poor campesino family, which had originally been active in the Communist Party. Medrano came in contact with the PRP and spent six months in China in 1969 studying in a Maoist leadership course. In 1973, a failed car bomb coordinated by the PRP lead to the arrest of the PRP's leadership. As a result, Medrano became the leader of the PRP in $1973 .^{7}$

Guzman was the leader of Sendero Luminoso. Sendero Luminoso was a radical Peruvian movement that attempted to create a nation wide revolution against bourgeois Peru. Originally a professor in education, Guzman joined the Peruvian Communist Party in 1958 and studied Maoism in China in both 1965 and 1967. Upon returning to Peru in 1967, Guzman established himself in Ayacucho and in 1970 separated from other Communist Parties to form the Communist Party Sendero Luminoso. ${ }^{8}$ Throughout the 1970s, Guzman's movement absorbed other radical movements within the area, until 1978. The movement then attempted to both expand geographically and initiate revolution. This revolutionary action was affirmed in 1980, when Senderista militants invaded an elections office and burned ballot boxes from the general election.'

To understand the difference between both leaders' interpretations of Maoism, and therefore their groups' actions, this paper will examine the attitudes each revolutionary group held towards the established society, towards the population the group was attempting to mobilize and towards its own group's members. This paper argues that Sendero Luminoso emphasized militaristic aspects of Mao's ideology, focusing on violence and action. The PRP and PPUA, under Medrano's leadership, emphasized the economic reality of a Maoist movement, focusing on the function of a Maoist society. As this paper further addresses, there are of course discrepancies between both claims. Finally, this paper will conclude that the ultimate difference between both movements shows the difficulty in re-creating a revolution based on Maoist ideology. The primary difficulty is simply that neither Peru nor Mexico had the same social or political situation as Mao's China.

\section{Maoism and the Established State}

Maoism outlined a very specific relationship between both those adhering to Maoist theory and the established society these individuals existed in. As Mao himself wrote, the state is to be understood as regressive ${ }^{10}$, while the revolutionary movement is to be progressive ${ }^{11} \cdot{ }^{12}$ Both the established state

\footnotetext{
${ }^{6}$ Matthew Rothwell. Transpacific Revolutionaries: The Chinese Revolution in Latin American. (University of Illinois at Chicago: 2009) 12

7 Rothwell, 46.

8 Rothwell, 88.

${ }^{9}$ Gustavo Gorriti, The Shining Path: A History of the Millenarian War in Peru. (Chapel Hill: University of North Carolina Press, 1999)17.

${ }^{10}$ Regressive should be understood as detrimental to the true will of the people.

11 Progressive should be understood as inspired by the will of the people, to develop towards a better political state.

12 Mao Tse-Tung, Selected Works of Mao Tse-Tung Volume 1. (London: Progressive Publishers1954) 45.
} 
and its economic hierarchy are seen as contradictions. ${ }^{13}$ That is to say, their existence is in constant struggle. Maoism attempted to regulate contradictions within both the established state and its economic hierarchy. Therefore, both are seen as enemies of the revolution and contradictions that this revolution must resolve. As a result, Mao argued for national liberation, a violent struggle to remove this contradiction. ${ }^{14}$ However, the idea of "national" pertained to a group liberating those within their identity. Mao did not specify what he meant by this identity. It could be interpreted as a global proletariat (or other group repressed by capitalism), but it could also be interpreted as a specific ethnic or cultural group. Regardless of definition, it is key to Maoist theory that this group took violent action against those oppressing it. History, according to Mao, was a struggle between peace transforming into war and war transforming into peace. ${ }^{15}$ This process was led by contradictions within the society. Violent action therefore allowed for transitions in history. As Mao proposed, "War is the highest form of struggle between nations, states, classes, or political groups." 16 The purpose of this war is to achieve the desired outcome of the class initiating the conflict "to win victory for itself." in an attempt to realize the goals of the subordinate class.

As previously discussed, the understanding of the subordinate class was not forced into a strict framework outlined by who controls the means of production. As political theorist P. Fedoseyev proposed, Mao's “view of development is that in the course of movement each opposite occupies the position which had earlier been occupied by its opposite."18 Development came by eliminating the opposing cause of a contradiction. The result was a transition where the suppressed class would become the ruler and could create social systems to their benefit. However, because Mao failed to define the result, this transition was ambiguous. It could either be a society where the bourgeois were literally the new proletariat or a society where the power relation itself is transitioned to benefit the proletariat. Either way, Mao saw the new established economic order as a project of the goals and desires of the group initiating the Maoist movement. The result is therefore a society created to benefit the movement's goals, since society initiated the violence to achieve this result. Because of this, there is no space for petty-bourgeois within the Maoist end goal. ${ }^{19}$ They placed within this dichotomy, and unlike in Marxist theory, the petty-bourgeois cannot embrace the goals of the newly established society.

To summarize, Mao outlined a relationship of a Maoist movement with the established society as the following: first, the established society and state were detrimental to progress; second, liberation from the established society was a national project, with nationalism defined as a group with common interests and identities; finally, violence was the only action to be taken to create a new order. In an attempt to measure the adherence to this section of Maoist theory, this paper compares both Senderos Luminoso and the PRP and the dialogue these two Maoist movements created towards the state.

Sendero Luminoso's relationship with the established Peruvian society and society's economic order focused on the potential for a violent conflict. Sendero focused on violence in an attempt to emphasize Mao's progression of history. As Abimael Guzman himself proposed, "One era has

\footnotetext{
13 Ibid., 23.

14 Ibid.

15 Ibid., 25.

16 Ibid.

17 Ibid.

18 P. Fedoseyev. Maoism Unmasked (Moscow: Progress Publishers, 1972), 24.

${ }_{19}$ Mao Tse-Tung, 23.
} 
ended. The preparations for a new one have been complete... The key is action. The objective is power." 20 The ending era Guzman referenced was the era of a Peru ruled by the bourgeois. Guzman therefore labeled the established society as a contradiction that can only be solved through action. Guzman believed that the established society in Peru has "exploited, subjugated and implacably oppressed." 21 This oppression had occured at the cost of marginalized classes. Steve Stern proposed that Sendero Luminoso was a creation of leftist politics and social discontent. ${ }^{22}$ However, Stern clarified that this discontent was based in political culminations that marginalized and ignored lower classes. ${ }^{23}$ Therefore, Sendero Luminoso's actions were to be understood as against history, if history means to following the previous "progressions" of Peruvian society. This related directly to Maoism, and its attempts to invert society.

The potential for Sendero Luminoso to have emphasized Maoism's militarism becomes evident here. Guzman highlighted this, as he proposed that Marxist movements have taught his followers "what it means to annihilate in order to preserve." 24 Guzman therefore directed the Sendero Luminoso to confront the entire established Peruvian society, as he outlined the enemy of the movement as all of capitalism. This led Guzman to foreshadow the violent intent of his movement. He argued Sendero Luminoso could create a new "powerful proletariat... invisible, and capable of creating a truly new order." 25 Guzman could predict the "bloodbath" Sendero Luminoso was soon to face. ${ }^{26}$ Guzman himself emphasized a militaristic interpretation of Maoism, as he focused on the impending conflict with the established society in Peru. As a result, Sendero Luminoso targeted the wider Peruvian society and saw little room for compromise. Violence was therefore emphasized as key to the elimination of this society. However, as Remi Kauffer outlined, the reality of a communist movement often diverged more into the perception of violence, which emphasized terrorism over armed uprising. ${ }^{27}$ Kauffer clarified that terrorism presented itself as a small group committing acts of violence against specific targets, whereas armed uprising was the product of a popular movement. ${ }^{28}$ This emphasis on terrorism is seen in the reality of the Sendero Luminoso's actions.

As much as Sendero Luminoso emphasized violence against the established Peruvian society, the reality of their actions was limited both by the size of the movement and the movement's accessible means. Although this is not the focus of this paper, the reality of the Maoist philosophy is important to address. Ivan Hinojosa argued that Sendero Luminoso attempted to create itself within a radical image. ${ }^{29}$ This statement can be further understood by comparing Guzman's dialogue with Maoism, as is presented in the previous paragraph. Sendero Luminoso would remove itself from democratic processes as a critique of the established Peruvian society. Limited size and means of the movement failed to allow it to create a complete revolution. As Kauffer put forth, most radical leftist groups

\footnotetext{
20 Abimael Guzman "We are the Initiators" in Starn, Orin, Degregori, Carlos Iván and Kirk, Robin. editors. The Peru Reader: History, Culture, Politics, $2^{\text {nd }}$ edition. (Durham: Duke University Press, 2005), 326.

21 Ibid.

22 Steve Stern. "Introduction" in Stern, Steve J. editor. Shining and Other Paths: War and Society in Peru, 1980-1995

(Durham: Duke University Press, 1998), 20.

${ }^{23}$ Ibid.

24 Abimael Guzman. El Diario, July 24th, 1998.

25 Abimael Guzman "We are the Initiators," 326.

26 Abimael Guzman. El Diario,

${ }^{27}$ Remi Kauffer. "Communism and Terrorism," in The Black Book of Communism edited by Mark Kramer (London: Harvard University Press, 1999), 353.

${ }^{28}$ Ibid.

${ }^{29}$ Ivan Hinojosa, "On Poor Relations and the Nouveau Riche: Shining Path and the Radical Peruvian," editor Steve I. Stern, Shining and Other Paths: War and Society in Peru, 1980-1995 (Durham: Duke University Press, 1998$), 61$.
} 
failed to develop mass popular support, and were normally limited by the violence of their actions. ${ }^{30}$ Within the Peruvian context, the militaristic interpretation of Maoism alienated potential supporters, as Hinojaso cited, in the wider Peruvian left. ${ }^{31}$ However, Sendero Luminoso remained in conflict with the established Peruvian society, as it never ceased to denounce democracy or turn away from armed struggle. ${ }^{32}$ The reality of Guzman's interpretation of Maoism limited the success of Sendero Luminoso.

Florencio Medrano's interpretation of Maoism emphasized a relation of seclusion from established Mexican society in an attempt to create a Maoist community. Medrano, therefore, focused more on the economic reality of his movement. Rothwell proposed previous Mexican Maoist movements, such as the movement led by Vicente Lombardo Toledano, had tried too hard to mimic Mao's revolution, without realizing the differences between both Mexico and China. ${ }^{33}$ Critical of these past failures, Medrano emphasized the uniqueness of Mexican society within his movement. Although Medrano obviously believed Mao's criticism of bourgeois society, the actions he took differed from those taken by Guzman. The first example of this is Medrano's 1973 Cuernavaca land claim. High members of Medrano's council argued that this land claim differed from other urban movements during the same time-period due to its Maoist inspiration. ${ }^{34}$ The Cuernavaca land claim allowed for the creation of a Maoist community on a small scale, which was named Colonia Ruben Jaramillo. Communal work programs, equal division of land and basic amenities insured by Medrano and his leadership, highlighted this community's Maoist sentiment. ${ }^{35}$ As Medrano himself proposed "I want to make the Jaramillio settlement the first people's commune of the Mexican Republic." "36 Unlike Guzman, Medrano believed that conflict with the established order of Mexico could come after the creation of Maoist ideal. Medrano clarified this sentiment when he proposed the Cuernavaca community served to develop political dissent towards the state within an established settlement. Therefore, he could manipulate the outside ties of this community to create broad support for armed struggle. ${ }^{37}$ The relation of the PRP with the state is not nearly as direct as with Sendero Luminoso.

Instead of entering into a direct conflict with the established order, the PRP, under Medrano's leadership, emphasized Mao's economic order over his militaristic actions. This emphasis is evident in the group's attempt to affirm its own existence and the validity of its theories regionally, within a single community. However, Medrano and his followers were still actively preparing for an armed struggle as he and his guerrillas began to carry arms openly and train new recruits. ${ }^{38}$ The result was an armed, self-governing area adhering to Maoist philosophy. Medrano's interpretation of Maoism emphasized the realization of a new society, established against the contradictions of the current economic order. By arming and training members in the community, Medrano was both preparing to use violence both as Mao directed (to create a new society), as well as preserve the established community Medrano was leading. Whether directed towards expansion or not, the result is a preservation of the newly established order.

\footnotetext{
${ }^{30}$ Kauffer, 355.

31 Ibid., 77.

32 Ibid., 76,

33 Rothwell, 42.

34 "La guerrilla se extiende por todo el pais." National Security Archive at George Washington University. http:// www.gwu.edu/ nsarchiv/NSAEBB/NSAEBB180/070-Grupos\%20armados.pdf, 436.

35 Ibid., 437.

${ }^{36}$ Elena Poniatowska, Fuerte es el silencio (Mexico City: Ediciones Era, 1980), 199.

37 Poniatowska, 202.

38 Poniatowska, 256.
} 
In relation to the established society, the key difference between Guzman's Maoism, and Medrano's Maoism is the direct sense of militarism. Guzman emphasized violent actions against the state to adhere to Mao's desire to remove contradictions. Medrano attempted to create a community without contradictions prior to a wider revolution. Both these interpretations of Maoism have flaws. Guzman failed to create a complete and concrete support base for his revolution, while Medrano failed to create a society without contradiction. For example, Poniantowska argued the new community did not eliminate high levels of crime or indoctrinate Maoism with all its members. ${ }^{39}$ The Shining Path and PRP differed in their interpretation of Maoism in relation to the revolutionary population both groups were attempting to mobilize.

\section{Maoism and the Revolutionary Population}

Mao's philosophy based its relationship with the revolutionary population on both nationalism and populism. Mao defined his revolutionary movement as a "People's War," requiring a specific sense of a population. ${ }^{40}$ As was previously discussed, Mao labeled this "People's War" as a national liberation, therefore requiring a specific sense of unity within a revolutionary movement. ${ }^{41}$ However, Mao did not specifically define what limited this nationality. Because of this, Maoism could potentially be adapted to different societies and contexts. The importance was only to specifically realize a revolutionary identity that only included the groups that the revolution was going to support. This is crucial, since Mao proposed that the revolution served to highlight and realize the desires of the population that initiates it. ${ }^{42}$ The revolution must adhere to a specific national identity, no matter how the movement interprets "national." National could either focus directly on a single cultural and ethnical identity. At the same time, it could also relate more so to the wider proletariat identity. The importance is that the group had common desires and goals, to frame the outcome of their revolution.

There are certain factors Mao required in his revolutionary population. However, what he outlined as crucial expands beyond Marxism. This departure from Marxism was an attempt to prevent his writings from being limited by a strict Marxist interpretation. The first of these is the basis of an agrarian society. ${ }^{43}$ Mao proposed that the peasantry could be the revolutionary force, as he argued any group alienated by society's contradictions could initiate revolution. ${ }^{44}$ However, since Mao never defined exactly what was required to create a national identity, the revolution was not limited only to the peasantry. In this sense, the peasantry served as China's example of a group marginalized by the contradictions of both imperialism and capitalism. Mao outlined the progression of the revolution as follows. The revolution should first affirm itself in an area largely exempt from the control of the established order. ${ }^{45}$ Once this movement affirmed a revolutionary base, it could then spread through the countryside initiating policies to gain popular support. ${ }^{46}$ Finally, the movement could take over urban areas, progressing from smallest to largest. ${ }^{47}$ The population within the revolution therefore progressed from a specific group of disciplined supporters to larger populations within a similar social context and concludes by affirming itself within populations of different social circumstances.

\footnotetext{
39 Poniatowska, 198

40 Mao, 23

41 Ibid.

42 A. Rumyantsev. "Maoism and Its Anti-Marx Philosophy" in n Maoism Unmasked (Moscow: Progress Publishers, 1972), 45.

${ }^{43}$ Mao Tse-Tung. The Correct Solution of the Contradictions Within a Nation. (Moscow: Russian Press, 1957$), 26$.

44 Ibid., 28.

45 Ibid., 30.

46 Ibid.

47 Ibid.
} 
It is key that the movement transitions from a small guerrilla movement to a mass movement, directly capable of targeting social contradictions. Both Sendero Luminos and Medrano, through the PRP, differed in their interpretation of this section of Maoist thought. Sendero Luminoso's focus emphasizes the progression of revolution, while the PRP highlighted an attempt to establish a revolutionary base.

Sendero Luminoso attempted to revolutionize Peruvian peasants, with the hopes to swiftly initiate the revolution. Militarizing therefore became more significant than emphasizing the Maoist idea of creating a revolutionary base. A clear example of this can be seen in Nicario's memoir. Nicario, a young peasant, joined Sendero Luminoso and soon became an active member in the movement. This young peasant claimed to have joined Sendero when it "still didn't really exist." 48 However, his dialogue emphasized Sendero's focus on action. Within a short period of time Nicario had already been led to blockading roads, setting off dynamite, and eventually participating in the assault on the University of Huamanaga's farm, Allpachaka. ${ }^{49}$ There was a practicality in this sort of action, because the animals at Allpachaka were used to feed the community. However, this sense of idealism was soon lost. As Nicario later exposed, communal work efforts were "no longer for the community, but to supply the comrades in the field." 50 This is in direct relation with what Ponciano del Pino H. claimed distanced peasants from Sendero Luminoso. Del Pino H. proposed that Sendero's authoritarian and hardening political line pushed peasants away from the movement. ${ }^{51}$ Pascal Fontaine clarified Del Pino H.'s proposal, as he puts forth the idea that Sendero Luminoso focus was on revolutionary expansion instead of popular support. ${ }^{52}$ Fontaine argued that the movement's emphasis on creating public fear garnered only the illusion of support. ${ }^{53}$ The reality was that Sendero became a weak movement with only a few capable commandos bound to come in conflict with their supposed supporters. Del Pino H. argued this failure to develop supporters widened Sendero's enemies. Sendero was not only at war with the established Peruvian Society, but also in conflict with the "chutos," the poorest peasants the movement was supposed to support. ${ }^{54}$ As this paragraph proves, Sendero Luminoso emphasized the revolutionary process before establishing a basis for its support. This process ultimately weakened the movement and fractured potential supporters. However, this was not the only flaw in Sendero Luminoso's attempt at Maoist philosophy.

The reality of Peruvian society limited Sendero Luminoso's ability to create a single national identity. As a result, the movement failed to create a unified movement with a common desired outcome. Marisol de la Cadena claimed that Peruvian society had been established with race as completely connected to social hierarchies. ${ }^{55}$ De la Cadena argued even as society and its intellectuals supposedly transitioned towards a societal evaluation based in notions of "culture" and class, this largely failed to break social evaluation based on race. ${ }^{56}$ Even Abimael Guzman and his leading

\footnotetext{
48 "Nicario." "Memories of a Cadre" in Starn, Orin, Degregori, Carlos Iván and Kirk, Robin.editors. The Peru Reader: History, Culture, Politics, 2nd edition (Durham: Duke University Press, 2005), 344.

${ }^{49}$ Ibid., 345.

50 Ibid., 347.

51 Ponciano del Pino H, "Family, Culture and "Revolution": Everyday Life with Sendero Luminoso." in Stern, Steve J. editor. Shining and Other Paths: War and Society in Peru, 1980-1995 (Durham: Duke University Press, 1998$), 162$.

52 Pascal Fontaine, "Communism in Latin America," in The Black Book of Communism edited by Mark Kramer (London: Harvard University Press, 1999), 677.

${ }^{53}$ Ibid.

${ }^{54}$ Del Pino H, 162.

55 Marisol de la Cadena. "From Race to Class: Insurgent Intellectuals de provincia in Peru, 1910-1970," in Shining and Other Paths: War and Society in Peru, 1980-1995, editor Steve I. Stern (Durham: Duke University Press, 1998$), 23$. 56 Ibid.
} 
commanders had been products of this very mind set. ${ }^{57}$ The Peruvian emphasis on race made it difficult to achieve what Mao argued was crucial for a revolution: a single national identity. Del Pino H. claimed that this was emphasized while he conducted fieldwork, with Sendero members, labeling chutos $^{58}$ as "brutish and ignorant." 59 As a result, Sendero Luminoso's discussions on "equality and justice for peasants [became] contaminated by an ethnic discourse... to [reveal] repugnance, intolerance, and racism." ${ }^{60}$ Ethnic minorities, such as Ashaninkas, were labeled as "parasitic burdens, useless, disposable." ${ }^{11}$ The examples of Sendero's own radicalizing of Peru could continue, but it is important to note that this itself was detrimental to the creation a single revolutionary identity. As was discussed early, Maoism argued for a single revolutionary identity, with common desires. This identity was to be implicated under common capitalist contradictions. However, race in Peru was a contradiction that a revolutionary movement such as Sendero Luminoso could not resolve. Race in Peru limited the potential of creating a unified Maoist movement. As Del Pino H. summarized, peace in the countryside could never be a reality. ${ }^{62}$ As a result, no single revolution identity could emerge.

This is not to say that Sendero Luminoso was completely disconnected from Peruvian rural society. Sendero managed to have an elaborate understanding of the capitalist contradictions that the rural populations of Ayacucho, Allpachaka and Huayllapampa were implicated underneath. Although this strays moderately from the topic of this paper, Colin Harding argued that many of these intellectuals found inspiration in Maoism, as a result of the of the fact that Peruvian government failed to adequately understand the social situation in these areas. ${ }^{63}$ Colin Harding exemplified Diaz Martinez, an official in the agrarian reform department, as an individual who had an awareness of the failures of past land reform attempts. These past attempts had done very little to change "the predominantly 'feudal' character of Ayacucho agriculture and rural society." ${ }^{64}$ This inspired Sendero Luminoso, who believed that they could acknowledge "old traditions of self-help and cooperation which were still there if only they could be brought out and developed." ${ }^{\prime 5}$ Even if there were limits to Sendero's ability to understand Peru, the movement did somewhat acknowledge the reality of certain peasant issues.

This previous discussion of failures should not discredit the historic development of Sendero Luminoso prior to the revolution. It is of course important to acknowledge their development within the rural university system. As Harding citied, the development of Sendero allowed it to be the leading force in university politics, as the movement made both teaching appointments and outlined potential classes for its own students. ${ }^{66}$ This promoted the development of leftist theories within the countryside. However, this action may have served only to develop the intellectual elites, instead of a wider revolutionary base within the Peruvian peasants.

In contrast, Florencio Medrano relationship with the population his movement attempted to mobilize held a more complete Maoist interpretation. First, Medrano himself emphasized the idea of

\footnotetext{
57 Ibid.

58 Poor Indigenous Peruvians

${ }^{59}$ Del Pino H. 163

60 Ibid.

61 Ibid.

62 Ibid.

${ }^{63}$ Colin Harding, “Antonio Díaz Martínez and the Ideology of Sendero Luminoso," in Bulletine for Latin American Research Vol. 7, No. 1 (January 1988), 67.

64 Ibid.

65 Ibid, 68.

${ }^{66}$ Ibid. 67
} 
"Mexican," as a cultural identity. Medrano catered his Maoist movement to poor campensino peasants, avidly critical of both intellectual leadership and the idea of superior identity. Medrano openly critiqued the leaders of other leftist movements, as he labeled them as "not Mexican.",67 Although this critique does seem to have the same potential racial connotations as in Peru, "not Mexican" was used to either label academics that had placed themselves as the leaders of popular leftist movements or ethnic groups who specifically desired their own identity. For example, Medrano refused to lead an uprising in Yucatan, a region historically known for its significantly Mayan heritage and Mayan population. ${ }^{68}$ Medrano, as a self labeled "Indígena mezclada con blanca" (of mestizo heritage) did not see any potential in his own leadership of this movement. ${ }^{69}$ Although there is a possibility that this refusal was linked to racial ties, as Barry Carr proposes, the identity of Mexican was largely linked to the mestizo population, since those of indigenous descent would identity themselves with their historical identity, and those of Spanish descent would ultimately do the same..$^{70}$ As a result, Medrano's land squatters' movement was established in an area where people of a similar mestizo identity could be reached. Rothwell argued that Medrano was taking advantage of the campesino agricultural crisis that was driving rural populations to urban centers. ${ }^{71}$ Rothwell credited this as the reason that the community had initial success as a Maoist movement. ${ }^{72}$ This was Medrano's attempt to access a single identity as to create the basis of a national identity. The result would be moderate successes within this community, successes similarly present in Medrano's ability to create a revolutionary basis.

Again, in contrast to Sendero Luminoso, Medrano's revolution focused first on establishing a basis for a Maoist society. This basis would be a population that would support Medrano's Maoist revolution. As was previously discussed, the realization of key infrastructure within Jaramillo increased the population's adherence to Maoist ideology. As Elena Poniatowska claimed, "almost everyone was enthusiastic to participate in the communal tasks. Installing drainage pipes, raising the church, fencing in the cemetery, the sports field and the children's playground were everyone's work." "73 Education was connected to productive labour, as Medrano coordinated "Red Sundays," a series of education, Marxist discussion, and labour initiatives aimed at youth in Mexico City and Cuernavaca. ${ }^{74}$ The population was therefore led to understand Maoist ideology and the benefits of Maoist values. However, even this ability to address the desires of the migrating population and connect them to Maoism did not provide an insured longevity for the Jaramillo community.

In a similar sense to Sendero Luminoso, the PRP's Cuernavaca land claim would ultimately fall apart due to a failure to adhere to Maoist ideology. As was previously discussed, by end of 1973 the community was deemed dangerous to the Mexican government. The result was an invasion coordinated by the Mexican Army and police force. ${ }^{75}$ The state maintained a military presence in the Jaramillio community until after 1980 in an attempt to maintain civil order and prevent any further leftist developments. ${ }^{76}$ Medrano had ignored the first step of revolution as was outlined by Mao. The

\footnotetext{
67 Poniatowska, 185

68 Ibid.

${ }^{69}$ Ibid.

70 Barry Carr, Marxism and Communism in Twentieith-Century Mexico (Lincoln: University of Nebraska Press, 1992), 108.

71 Rothwell, 49.

72 Ibid.

73 Poniatowska 190.

${ }^{74}$ Rothwell, 50.

75 Ibid., 52.

76 Ibid.
} 
very vicinity of the Jaramillo community to Mexico City made the community an immense concern for the state. The result was a violent response. This response attempted to eliminate something the Mexican government saw as a danger to their established society. ${ }^{77}$ As Rothwell summarized, "While Medrano was able to use the terrain and popular support to evade the state, he was never able to create a basis of operations that the police or army could not penetrate." ${ }^{78}$ This inability to completely commit to Maoist ideology would result in the failure of the land claim project.

Similarly, the Shining Path's emphasis on the action of the revolution was detrimental to their movement and resulted in many failures of a complete adherence to a Maoist ideology. The PRP, in adhering more to Maoist ideology, saw moderate success. The PRP managed to find this success while also addressing the economic reality of the population it attempted to mobilize. This can be seen in the administration of land to landless peasants, attempting to transition from rural to urban environment. At the same time, the creation of infrastructure allowed for the development of this community. Although adhering to Maoist ideology within an economic context allowed for moderate success, the failure of the movement would come in as a result of an inability to replicate Mao's own Chinese Revolution.

\section{Maoism and its Revolutionary Members}

The final section of Mao's theory this paper will analyze is the relationship Mao outlined for the revolutionary public, specifically, members within the movement. The previous section emphasized how the revolutionary base was created. This section serves to discuss what is done with this base once mobilized. To clarify, this paragraph discusses the relationship between the movement and its existing members. To begin, Mao outlined that direct members of his movement must not be distinct from the masses. ${ }^{79}$ These individuals were to be seen as direct leaders in the Cultural Revolution, with the purpose of both intensifying class struggle and socialism. ${ }^{80}$ Their targets included both the bourgeois and ideas of traditionalism. ${ }^{81}$ As Lin Piao clarified, the organization of armed individuals was to be focused around small groups coordinated with different purposes. Piao divided these responsibilities into four groups, "shock," "fire," "aid," and "escape." 82 The purpose of these groups was to create strategic events, through the coordination of small squads. ${ }^{83}$ These armed squads served as the movements military, as well they served a social purpose. These squads were to adhere to the idealism of Maoist thought and promote Maoist values. As Piao finalized, they were to emphasize reform, ideological training, and community security. ${ }^{84}$ Members of the revolutionary movement were to see themselves as Maoist exemplars, fully committed to the cause of the revolution. Therefore, they were required to adhere completely to the ideology of the leader, as commitment to the revolutionary cause leads to a personality cult of the leader. ${ }^{85}$ However, as both Sendero Luminoso and the PRP exemplified, translating the Maoist idealism to a revolutionary population proved a difficult challenge.

Sendero Luminoso emphasized its individual members were to participate directly in violent actions. Because of this requirement, the movement largely failed to have its individuals exemplify a

\footnotetext{
77 Ibid.

78 Rothwell, 53.

${ }^{79}$ Mao, Selected Works of Mao Tse-Tung, 55.

${ }^{80}$ Ibid.

81 Ibid

${ }^{82}$ Lin Piao, Long Live the Victory of People's War. (Peking: Foreign Languages Press, 1968).

83 Ibid.

84 Ibid.

85 Ibid.
} 
complete Maoist ideology. Sendero Luminoso was largely successful in creating a personality cult around Abimael Guzman. One anonymous "Oath of Loyalty" highlighted the success of this cult. The author characterized Guzman not only as the leader of the Peruvian revolution, but also the global proletariat, a party unifier. ${ }^{86}$ This oath also highlights the complete loyalty of members of Sendero Luminoso, as the author claims to have given "full and unconditional submission... [to] the entire system of Party leadership." ${ }^{\prime 77}$ As Michael Radu cited, the relationship between the individual member and the leadership figure played a crucial role in Latin American revolutionary movements. ${ }^{88}$ Radu clarified idealized leaders had the ability to command complete ideological following from their followers, allowing for an increased commitment to radicalism. ${ }^{89}$ Constantly, Sendero Luminoso had the ability to attempt to forward its revolutionary cause. Similarly, Sendero Luminoso members did manage to exemplify certain Maoist values, in the movements ability to create order within communities.

Sendero Luminoso coordinated organized communities and dealt with civil order through revolutionary justice. As del Pino H. classified, Sendero offered "concrete alternatives" to the structural issues within rural areas. ${ }^{90}$ Furthermore, Sendero Luminoso insured order, by punishing social degenerates, therefore promoting a morally better society. ${ }^{91}$ Although this statement is ridden with contradictions, especially in relation to the racial connotations of Sendero Luminoso and the rest of Peru, in some sense Sendero members promoted the values Mao outlined. Del Pino H. clarified it was the "generational and ethnic factors" that limited Sendero's success. ${ }^{22}$ Although it seems to have been the violent solutions to social issues that alienated sections of the population, it is difficult to criticize this as a misinterpretation of Mao's theory. Mao did, as previously discussed, emphasize that revolutionary members create civil justice. He also emphasized the use of violence to end contradictions. As a result, it is possible to label these social issues as contradictions within the potential revolutionary population. Solutions to social problems would both emphasize the inefficiencies of the state, while highlighting a contradiction that restricted the unity of the peasant population. The use of violence was restricted and it is possible to justify it within Maoist theory. The case, however, is somewhat different when discussing the PRP in Mexico.

The PRP held a very different relationship with its own members and, as a result, sought stability from local populations. However, the movement was not without its limitations. The first of these limitations took place in the squatters' community of Jaramillo. This failure took place because of Medrano's failure to provide local security within the community. The PRP failed to realize what Piao outlined as crucial to a Maoist movement: to providing security. As Rothwell proposed, Medrano's attempt to focus both on building projects and preparations for armed struggle shifted his focus from keeping the community politicized and mobilized. ${ }^{93}$ The result supports what Poniatowska's research affirmed, that civil obedience became a rarity. ${ }^{94}$ Criminals could, as Poniatowska explained, enter into Jaramillo, since neither the PRP, nor state police could insure

\footnotetext{
86 Anonymous, "Oath of Loyalty" in, The Peru Reader: History, Culture, Politics, 2 ${ }^{\text {nd }}$ edition, editors Orin Starn , Carlos Iván Degregori, and Robin Kirk (Durham: Duke University Press, 2005), 351.

87 Ibid.

${ }^{88}$ Michael Radu, Violence and the Latin American Revolutionaries (New Brunswick:Transaction Books, 1988$), 9$.

${ }^{89}$ Ibid.

${ }^{90}$ Del Pino H., 161.

91 Ibid.

${ }^{92}$ Ibid.

93 Rothwell 51.

94 Poniatowska 202.
} 
justice. ${ }^{95}$ These fractured community members could find neither security in the state nor the PRP. The PRP had began to use its military means to promote a revolution instead of security. This differed highly from the early establishment of Jaramillo, when the PRP emphasized local infrastructure and, as a result, security. Rothwell noted much of this infrastructure had begun to deteriorate without the PRP's support. Medrano represented a unique contradiction in Maoist thought. Although his early inclinations supported an economic understanding of Maoist theory, he eventually drifted away from this in an attempt to militarize and create a popular revolution.

After the failure of the Jaramillo community, Medrano fled to the border region between Oaxaca and Veracruz. He then renamed his party the PPUA. Here again, Medrano promoted Mao's ideology by promoting his guerrillas as Maoist idealists. First, Medrano proposed that his group always be directly involved with the communities they attempted to support, acknowledging Mao's request that the revolutionary force's military be indistinguishable from the revolutionary population. ${ }^{96}$ Ramon Perez, a PPUA member, claimed that Medrano always encouraged his militants to partake in construction projects and study Maoism. ${ }^{97}$ Although the PPUA would eventually disband after Medrano's death, for a time being, it noted moderate support and success. As Rothwell proposed, Medrano constantly found success in his adherence to Maoist theory, combined with the reality of Mexico. ${ }^{98}$ This could be understood as the realization that a Maoist movement needed to provide the basic amenities to the population it was attempting to revolutionize. Neither the PPUA nor the PRP managed to create a large scale revolution, but both movements managed moderate success by acknowledging the economic reality of the populations it was attempting to radicalize.

Sendero Luminoso emphasized radicalization within its members, promoting both revolutionary ideals and social security. The PPUA and the PRP, in contrast, emphasized the Maoist values that were required for the basis of the creation of a Maoist society. The PRP faced significant difficulty transitioning from this focus to a revolutionary focus. Sendero, however, emphasized total commitment, but simultaneously failed to find solutions to the reality of Peruvian society. As previously discussed, the reality of Peruvian society limited Sendero Luminoso's ability to develop as a full Maoist movement. However, the movement's emphasis on militarism severed their ability to connect with local populations. The PPUA or the PRP could not create a complete revolution, because they emphasized the economic reality and made the potential of armed revolution seem both distant and separate. The issue is, however, not how these groups misinterpreted Maoism, but more how Mao's China differed from the social reality of both Peru and Mexico.

\section{Conclusion}

This paper attempted to evaluate to what extent Abimael Guzman and Florencio Medrano adhered to Maoist thought, however, there are certain issues that must be addressed. The first of these issues involved the difference between the Maoist interpretation of each leader and the actions committed by their respective movements. There the question how true the ideological adherence of a movement's individual member was to their respective leaders' Maoist interpretation. This statement does not aim to disconnect the actions of either the members of Sendero Luminoso, the PRP or the PPUA from their respective leaders. But this limitation must be considered before evaluating a single leader's interpretation and actions. The individual members of a movement could have acted as individual agents without regard to the leadership of either Medrano or Guzman. However, this

\footnotetext{
95 Ibid.

${ }^{96}$ Ramon Perez, Diary of a Guerilla (Houston: Arte Publico Press, 1999), 67.

${ }^{97}$ Ibid., 106.

98 Ibid.
} 
does not limit the possibility of any of the claims made in this paper. Both movements would of course see significant disintegration after either the arrest of their leader (Abimael Guzman was arrested in 1992, and sentenced to life in prison) or death of their leader (Florencio Medreno was killed in action in 1978, in a conflict with Mexican Security forces). A second limitation is the difference of size between Sendero Luminoso and both the PRP and PPUA. As Rothwell asserted, Sendero Luminoso managed to create a revolutionary moment, while Medrano's movements only showed this as a potential. ${ }^{99}$ This could mean that Medrano's focus on the economic reality of Maoism and his attempts to create a Maoist society had limited his emphasis on revolution. It could also be that the very means at his disposal limited his revolutionary potential. Medrano may not have had a large support basis to radicalize. It is important to consider both of these limitations before drawing any conclusions on this topic.

As a result, it is difficult to assess if either Guzman's or Medrano's success was limited by their interpretation of Maoism. Guzman, through the Sendero Luminoso, emphasized violence and revolutionary action. His interpretation of Maoism outlined a direct conflict with the established order in Peru. He focused on initiating a revolutionary population, while requiring that Sendero's own members to engage in revolutionary activities (over Maoist community building). Medrano, through both the PRP and the PPUA, emphasized an economic understanding of Maoism. This emphasis is evident through the PRP's attempts to create a Maoist community before engaging in conflict with the state. This emphasis is also evident as both the PRP's attempt to create a population and the PPUA's attempt to create revolutionary members that adhered to Mao's theories on work and infrastructure. The key difference between both movements would therefore be that Sendero Luminoso attempted to serve as a revolutionary force, whereas the PRP and the PPUA focused on creating the framework for a new Maoist society. Neither group did find complete success.

Thus this paper has two conclusions. First, it is possible to conclude that Sendero Luminoso's ultimate end resulted in part to its failure to create a revolutionary base and solutions to social contradictions in Peru. Second, it is possible to conclude that Medrano's failure rests in his inability to create a revolutionary force, as he focused his movement on the creation of a Maoist society. However, it is best to understand these conclusions within the following framework. Although both groups attempted to create a Maoist movement based on the same philosophies, Sendero Luminoso and the PRP/PPUA each adhered to a different understanding of Maoism. However, both these movements were based in the social context of each society, which proved for both movements to be a limitation and ultimately in part responsible for the movements' eventual failure. This paper concludes that the greatest limitation for both Mendrano and Guzman was the fact that neither Peru, nor Mexico was identical to Mao's China. So while both Medrano's and Guzman's movements were characterized by different interpretations of Maoism, their inability to apply Maoism was the result of something else. Both Medrano and Guzman were initially limited because neither leader worked in a society that had the same political or social situation as Mao's China. So while Mao, Guzman, and Medrano were all in countries that held similar relationships to the "First" and "Second" worlds, the internal contexts of each country was very different. The final results were revolutionary movements could only emphasize the parts of Mao's theory that apply directly to their own national context. This showed both the limits of any revolutionary theory and the difficulty of recreating a revolution to reflect a previously successful movement. So although Maoism presented a Marxist theory for the Third World, in reality it was a theory specifically for China. As this attempt

\footnotetext{
99 Rothwell 46.
} 
to import a foreign revolutionary theory shows, there is a distinct disconnect between those who attempt to apply a revolutionary theory and the population to which the theory is applied. 


\section{Bibliography}

Anonymous. "Oath of Loyalty" in Starn, Orin, Degregori, Carlos Iván and Kirk, Robin. editors. The Peru Reader: History, Culture, Politics, $2^{\text {nd }}$ edition. (Durham: Duke University $\quad$ Press, 2005)

Carr, Barry. Marxism and Communism in Twentieth-Century Mexico. Lincoln: University of Nebraska Press, 1992.

De la Cadena, Marisol. "From Race to Class: Insurgent Intellectuals de provincia in Peru, 1910-1970.” in Stern, Steve J. editor. Shining and Other Paths: War and Society in Peru, 1980-1995. Durham: Duke University Press, 1998.

Del Pino H, Ponciano. "Family, Culture and "Revolution": Everyday Life with Sendero Luminoso" in Stern, Steve J. editor. Shining and Other Paths: War and Society in Peru, 1980-1995. Durham: Duke University Press, 1998.

Fedoseyev, P. Maoism Unmasked. Moscow: Progress Publishers, 1972.

Fontaine, Pascal. "Communism in Latin America," in The Black Book of Communism edited by Mark Kramer. London: Harvard University Press, 1999.

Gorriti, Gustavo. The Shining Path: A History of the Millenarian War in Peru. Chapel Hill, University of North Carolina Press, 1999.

Guzman, Abimael. “El Diario.” July 24th, 1998.

Guzman, Abimael. "We are the Initiators" in Starn, Orin, Degregori, Carlos Iván and Kirk, Robin. editors. The Peru Reader: History, Culture, Politics, 2nd edition. Durham: Duke University Press, 2005.

Harding, Colin. "Antonio Díaz Martínez and the Ideology of Sendero Luminoso" in Bulletine for Latin American Research Vol. 7, No. 1, January 1988.

Hinojosa, Ivan. "On Poor Relations and the Nouveau Riche: Shining Path and the Radical Peruvian." Stern, Steve J. editor. Shining and Other Paths: War and Society in Peru, 1980-1995. Durham: Duke University Press, 1998.

"La guerrilla se extiende por todo el pais." National Security Archive at George Washington University.http://www.gwu.edu/ nsarchiv/NSAEBB/NSAEBB180/070-Grupos $\% 20$ armados.pdf 
Kauffer, Remi. "Communism and Terrorism," in The Black Book of Communism edited by Mark Kramer. London: Harvard University Press, 1999.

Krivtsov, V.A. “Introduction” in Maoism Unmasked. Moscow: Progress Publishers, 1972.

"Nicario." "Memories of a Cadre" in Starn, Orin, Degregori, Carlos Iván and Kirk, Robin.editors. The Peru Reader: History, Culture, Politics, $2^{\text {nd }}$ edition. Durham: Duke University Press, 2005

Perez, Ramon. Diary of a Guerilla. Houston: Arte Publico Press, 1999.

Piao, Lin. Long Live the Victory of People's War. Peking: Foreign Languages Press, 1968.

Poniatowska, Elena, Fuerte es el silencio (Mexico City: Ediciones Era, 1980)

Radu, Michael. Violence and the Latin American Revolutionaries. New Brunswick:Transaction Books,1988.

Rothwell, Matthew. “Transpacific Revolutionaries: The Chinese Revolution in Latin American.” University of Illinois at Chicago, 2009.

Rumyantsev, A. "Maoism and Its Anti-Marx Philosophy” in Maoism Unmasked. Moscow: Progress Publishers, 1972.

Stern, Steve. "Introduction" in Stern, Steve J. editor. Shining and Other Paths: War and Society in Peru, 1980-1995. Durham: Duke University Press, 1998.

Tse-Tung, Mao. Selected Works of Mao Tse-Tung Volume 1. London, 1954.

Tse-Tung, Mao. The Correct Solution of the Contradictions Within a Nation. Moscow: Russian Press, 1957. 